\title{
Combined Usage of Diode Laser "Granum" and "Emdogain" (Straumann) During Surgical Phase in Treatment of Generalized Periodontitis
}

\author{
Biloklytska Galyna and Braun Iuliia* \\ National Medical Academy of Post-Graduate, Education named after P.L. Shupyk, Dental Scientific Practical Medical Center, Kyiv, Ukraine
}

Received: July 31, 2014; Accepted: September 15, 2014; Published: November 07, 2014

*Corresponding author: Braun Iuliia, Department of conservative dentistry, National Medical Academy of Post-Graduate, Education named after P.L. Shupyk, Dental Scientific Practical Medical Center, Kyiv, Ukraine, E-mail: julia8braun@gmail.com

\begin{abstract}
The effective treatment of Generalized Periodontitis (GP) is among main priorities in modern dental treatment. Most of surgical techniques aim to provide regeneration of lost periodontal tissues, using modern Minimally Invasive Surgical Techniques (MIST), devices. According to Biloklytska G, the effective treatment of GP is very actual for citizens of Ukraine, where statistics of disease prevalence shows very high percent of patient involvement. In the review the evidence for combined usage of the diode laser and Enamel Matrix Proteins (EMP) will be showed, the applied treatment approaches will be compared and discussed, clinical occasion will be showed.
\end{abstract}

Keywords: Periodontal disease; Emdogain; Diode laser; Periodontal regeneration

\section{Introduction}

According to the modern literature data [1-5] the evidence for details of complete pathological mechanism occurring during periodontal disease is still absent [5-10], the same appears with understanding and management of periodontal regenerative mechanisms $[4,5]$. But regenerative periodontology becomes to be more and more actual branch of dentistry [4-7] because tooth saving procedures are among priorities for the patient benefits and qualitative work of dispensary system in dentistry. The development of Minimally Invasive Surgery (MIS) according to Harrel SK and Rees TD [8], Minimally Invasive Surgical Technique (MIST) and modifications according to Cortellini P and Tonetti M $(2007,2005)[4,5]$ for periodontal treatment, the usage of EMD [5-7, 9-11,] and diode laser application [12], ultrasonication [1], with their clinical benefits, became to be reality in periodontology nowadays [12-17]. Modern treatment approaches aims to be simplified and mostly based on maintenance of biological mechanisms during tissue healing after applied procedures [4,12,17-20]. Until present time regeneration of periodontal tissues affected by chronic GP, it is under major scientific and clinical interest [7,13,17-20]. Taking into consideration the prevalence score of GP in Ukraine - 92.6\%, where the predominant affect of the disease occurs among working contingent of patients in age of 40 years (86\%) and it still constantly takes first rate among factors leading to the tooth loss. GP rates first place among main reasons for tooth extraction in the country. The prevalence of GP in different regions of Ukraine among citizens in age of 19-33 years was: in western part - 95.4\%, in northern part $-83.4 \%$, in eastern part $-84.7 \%$, in southern part - $92 \%$. It can be concluded that development and introduction of modern treatment approaches in periodontology should be economically reasonable and provide minimally invasive approaches for patients, being dedicated mainly to the tooth saving procedures that are among main priorities nowadays.

According to the modern literature data there is still no exact evidence about details of complete pathological mechanisms occurring during a periodontal disease where the same situation occurs with periodontal regenerative mechanisms $[4,5,9,13,17]$. In 1997, it became clear that, in addition to the role of Enamel Matrix Proteins (EMP) in enamel formation process, the hydrophobic ectodermal proteins EMD ("Emdogain", Straumann) play a novel role in the regeneration of periodontal tissues $[7,17]$. The healing process of periodontal tissues after surgical procedures is crucial for their regeneration and patient comfort $[4,5,12,17]$. The main aim of surgical phase in treatment of GP is to reconstruct the lost periodontal structures under support of biological regenerative process $[4,5,17]$.

Moritz et al. [14] determined presence of $A$. actinomycetemcomitans not only colonizing on to the periodontally diseased root surface, but also invading adjacent soft tissues and that makes eradication more difficult when using only mechanical periodontal instrumentation. The modern tendencies have defined more accurate procedures that can be provided on periodontal tissues. They can minimize the volume of applied surgical procedure and should be maximally patient oriented, supplying high percent of clinical success $[4-6,12,17,19,20]$. Kreisler $\mathrm{M}$ et al. [10] demonstrated that proliferative activity of ligament fibroblasts was considerably higher after 890$\mathrm{nm}$ wavelength diode laser irradiation. Sakurai Y. et al. [16] indicated that irradiated cells produced less Prostoglandin E2 
(PGE2) and Cycl-0-Oxynase (COX), indicating the possible antiinflammatory role of the diode laser which may have therapeutic effect on aggravation of periodontitis. Moritz A. et al. $[14,15]$ concluded that the diode laser treatment following scaling and root planning had a bactericidal effect and reduced inflammation. Also Moritz A et al. [15] determined reduction of Actinobacillus actinomycetemcomitans in patients received laser treatment. Coleton S [3] indicated about usage of the diode lasers adjunct to periodontal surgery, leading to decrease of inflammation level. Andreana S [2] concluded that laser should be used as an adjunct to conventional therapy both for its decontaminating and biostimulating effects.

\section{Materials and Methods}

The 17 patients were taken for treatment with chronicmoderate GP (PD 5-7 mm, intra-bony defect involving 1/3 sides of the root, with interdental space $>2 \mathrm{~mm}$ ) that were undertaken for complex individualized treatment of GP in Dental Scientific Practical Medical Centre (Kyiv, Ukraine), including surgical phase. Oral hygienic and endodontic procedures were applied properly. Traumatic occlusion check-up and temporary splinting procedures were provided previous to surgical phase. All patients were non-smokers and are generally healthy.

Depending on type of applied surgical procedures, patients were devided into two groups: Group I - basic (10 patients) - the flap operations according MIST approach [3] were provided in combination with "Emdogain" (Straumann) and simultaneous ultrasonication of roots and bone pockets ("Cavitron SPS", Dentsply) and curretage with flap deepithelization under diode laser irradiation ("Granum", 980 nm, 2 watts, continuous regimen). Group II - control (7 patients) - the flap operations with MIST approach were applied only in combination with "Emdogain" and curettage by hand currets (Hu-Friedy) (Table 1).
During hygienic phase the following periodontal indexes were assessed: (PI) Plaque index, (BOP) Bleeding on Probing Index, (PD) Pocket Depth, (SMI) Schour-Massler index), type of exudate from periodontal pocket, tooth mobility. The presurgical tissue preparation was provided after hygienic phase. The supra-gingival scaling and polishing were provided during this phase by hygienist. The permitted depth of penetration into the periodontal pocket was no deeper than $2 \mathrm{~mm}$ sub-gingivaly. The precise and accurate cleaning in area of the interdental spaces was applied. The results are presented in (Table 2).

The presurgical observation of patients included index assessment of PI, BOP, PD, PMA, SMI, (CAL) Clinical Attachment Loss, type of exudate from periodontal pocket, tooth mobility. The flap operations were applied in premolar and molar areas of upper and lower jaws. The tissue preparation before flap operation was staged under dynamic evaluation of main periodontal indexes.

The pre-operation tissue preparation was applied in both groups and included pre-surgical phase (Table 3), including simultaneous diode laser ("Granum") curettage under local anesthesia. The pre-surgical phase included: supra-gingival and sub-gingival scaling and root planning with usage of hand instruments ("Hu-Friedy" currets), ultrasonication ("Cavitron SPS", Dentsply) in combination with diode laser curettage ("Granum", wave length - $980 \mathrm{~nm}, 2.0$ watts, continuous regimen) under local anesthesia. The pre-surgical phase procedures were repeated 2 times with interval of 7 days in an aim to provide progressive reduction of tissue inflammation before surgery. Laser irradiation was applied during curettage procedure in aim to reduce amount of residual visible granulations, to provide additional bactericidal and biostimulative effects. The processed tissues were irrigated by "Decasanum" $0.02 \%$ and "Betadine" $10 \%$. After each presurgical phase $0.05 \%$ Chlorhexine (CHX)

Table 1: Distribution of patients according groups and applied surgical phase details.

\begin{tabular}{|c|c|c|c|c|}
\hline \multirow[b]{2}{*}{ Group of patients } & \multicolumn{4}{|c|}{ Details of surgical phase } \\
\hline & $\begin{array}{c}\text { Surgical } \\
\text { approach }\end{array}$ & Root and bone pockets debridement & Curettage methodic & $\begin{array}{c}\text { Deephitelization } \\
\text { methodic }\end{array}$ \\
\hline $\begin{array}{c}\text { Main } \\
\text { (10 patients) }\end{array}$ & MIST & Ultroconicotion & \multicolumn{2}{|c|}{ Diode laser + hand currets } \\
\hline $\begin{array}{c}\text { Control } \\
\text { (7 patients) }\end{array}$ & Emdogain & Uitrasonication & \multicolumn{2}{|c|}{ Hand currets } \\
\hline
\end{tabular}

Table 2: The hygienic phase details and periodontal indexes value.

\begin{tabular}{|c|c|c|c|c|c|}
\hline $\begin{array}{l}\text { Treatment } \\
\text { phase }\end{array}$ & $\begin{array}{l}\text { Primary index } \\
\text { assessment }\end{array}$ & $\begin{array}{l}\text { Procedure stages: } \\
\text { I procedure }\end{array}$ & $\begin{array}{l}\text { Interval } \\
\text { (days) }\end{array}$ & Reevaluation: & $\begin{array}{l}\text { Treatment } \\
\text { phase }\end{array}$ \\
\hline \multirow{5}{*}{$\begin{array}{l}\text { Hygienic } \\
\text { phase }\end{array}$} & \multirow{5}{*}{$\begin{array}{c}\text { 1) } \mathrm{PI}=40 \% \\
\text { 2) } \mathrm{BOP}=60 \% \\
\text { 3) } \mathrm{PMA}=50 \% \\
\text { 4) } \mathrm{PD}=5-7 \mathrm{~mm} \\
\text { 5) Tooth mobility - } \\
\text { 1-2 stage } \\
\text { 6)Exudate - serouse, } \\
\text { presence of pus no less } \\
\text { than in } 3 \text { periodontal } \\
\text { pockets per sextant }\end{array}$} & Motivation & \multirow{5}{*}{$\stackrel{7 \text { days }}{\longrightarrow}$} & \multirow{5}{*}{$\begin{array}{c}\text { 1) PI = } 30 \% \\
\text { 2) BOP }=50 \% \\
\text { 3) PMA }=40 \% \\
\text { 4) Tooth mobility } \\
-1-2 \text { stage } \\
\text { 6) Exudate - serouse, } \\
\text { presence of pus in 1-2 deepest } \\
\text { periodontal pockets per } \\
\text { sextant }\end{array}$} & \multirow{5}{*}{ Presurgical phase } \\
\hline & & $\begin{array}{l}\text { Oral } \\
\text { hygiene instructions: Bass technique } \\
\text { and interdental brushes }\end{array}$ & & & \\
\hline & & $\begin{array}{l}\text { Supragingival scalling and root } \\
\text { planning of all teeth }\end{array}$ & & & \\
\hline & & & & & \\
\hline & & Polishing of old fillings & & & \\
\hline
\end{tabular}


Table 3: The presurgical phase details and periodontal indexes value.

\begin{tabular}{|c|c|c|c|c|c|c|c|c|}
\hline $\begin{array}{l}\text { Treatment } \\
\text { phase }\end{array}$ & $\begin{array}{l}\text { Primary index } \\
\text { assessment }\end{array}$ & $\begin{array}{l}\text { Procedure stages: } \\
\text { I procedure }\end{array}$ & $\begin{array}{l}\text { Interval } \\
\text { (days) }\end{array}$ & $\begin{array}{l}\text { Reevalua- } \\
\text { tion: }\end{array}$ & $\begin{array}{l}\text { Procedure } \\
\text { stages: } \\
\text { II prodedure }\end{array}$ & $\begin{array}{c}\text { Interval } \\
\text { (days) }\end{array}$ & Reevaluation: & $\begin{array}{l}\text { Treatment } \\
\text { phase }\end{array}$ \\
\hline \multirow[t]{3}{*}{$\begin{array}{c}\begin{array}{c}\text { Presurgical } \\
\text { phase }\end{array} \\
\stackrel{\longrightarrow}{\longrightarrow}\end{array}$} & \multirow{3}{*}{\begin{tabular}{|} 
1) PI = 30\% \\
2) $\mathrm{BOP}=50 \%$ \\
3) $\mathrm{PMA}=40 \%$ \\
4) $\mathrm{PD}=5-7 \mathrm{~mm}$ \\
5) CAL $=1-2 \mathrm{~mm}$ \\
6) Tooth mobility \\
- $1-2$ stage \\
7)Exudate \\
- serouse, \\
presence of pus \\
in $1-2$ deepest \\
periodontal pockets \\
per sextant
\end{tabular}} & $\begin{array}{c}\text { Supra- and } \\
\text { subgingival scalling } \\
\text { and root } \\
\text { planning } \\
\text { of all teeth } \\
\text { under } \\
\text { local } \\
\text { anaesthesia }\end{array}$ & \multirow[t]{3}{*}{$\stackrel{7 \text { days }}{\stackrel{(}{ }}$} & \multirow{3}{*}{$\begin{array}{c}\text { 1) } \mathrm{PI}=20 \% \\
\text { 2)BOP }=40 \% \\
\text { 3)PMA }=30 \% \\
\text { 4) } \mathrm{PD}=4-6 \\
\mathrm{~mm} \\
\text { 5)CAL }=1-2 \\
\mathrm{~mm} \\
\text { 6)Tooth } \\
\text { mobility } \\
\text { - 1-2 stage } \\
\text { 7)Exudate - } \\
\text { serouse in all } \\
\text { sextants }\end{array}$} & $\begin{array}{l}\text { Supra- and } \\
\text { subgingival } \\
\text { scalling } \\
\text { and root } \\
\text { planning } \\
\text { of all teeth } \\
\text { under } \\
\text { local } \\
\text { anaesthesia }\end{array}$ & \multirow[t]{3}{*}{$\stackrel{7 \text { days }}{\Longleftrightarrow}$} & \multirow{3}{*}{$\begin{array}{c}\text { 1)PI }=13 \% \\
\text { 2)BOP }=33 \% \\
\text { 3) } \mathrm{PMA}=25 \% \\
\text { 4) } \mathrm{PD}=4-6 \mathrm{~mm} \\
\text { 5)CAL }=1-2 \mathrm{~mm} \\
\text { 6) Tooth mobility } \\
-1 \text { stage } \\
\text { 7)Exudate - } \\
\text { serouse in all } \\
\text { sextants }\end{array}$} & \multirow[t]{3}{*}{ Surgical phase } \\
\hline & & Laser curettage & & & Laser curettage & & & \\
\hline & & $\begin{array}{l}\text { Motivation and } \\
\text { hygienic recommen- } \\
\text { dations }\end{array}$ & & & $\begin{array}{l}\text { Motivation } \\
\text { and hygienic } \\
\text { recommen- } \\
\text { dations }\end{array}$ & & & \\
\hline
\end{tabular}

irrigations and applications with 3\% Hydrogen Peroxide $\left(\mathrm{H}_{2} \mathrm{O}_{2}\right)$ were prescribed for 3 times per day for 2 weeks. The hygienic habits control and patient's skills were realized every 7 days during visits. The criteria for over-passing to surgical stage were significant value reduction of periodontal indexes (Table 3).

The flap operation was provided according principles of MIS (Minimally Invasive Surgery) established by Harrel SK and Rees TD [8] and MIST which is established by Cortellini P and Tonetti $\mathrm{M}$ [3] with modifications for saving of the interdental papillae [2]. The flap elevation was provided only buccally for deep pockets access, excluding elevation palatally and lingually, preventing additional flap trauma regarding vascular breakage, oedema, and wound enlargement. All the periodontal tissues were preserved in aim to provide primary wound stability after surgery and prevent wound recontamination.

Subgingival root scaling and ultrasonication of adjacent bone were provided with "Cavitron SPS" (Dentsply). The criteria for complete ultrasonication were: scaled, planned root surface and bone, absence of visible adhered to the tooth surface calculus and residual soft granulations attached to the bone. Additional ultrasonication of elevated flap was provided till its dehematization, visible soft granulations were coagulated with diode laser (2.0 watts, continuous regimen, 1-2 sec exposure for each granulation tissue portion). The same procedure was applied in interdental area, saving papilla on place. The processed surfaces were irrigated by "Decasanum" $0.02 \%$ and "Betadine" $10 \%$. The final flap and inter-dental area degranulation from both sides in basic group were realized due to diode laser "Granum" irradiation, deepithelization of flap margin (0.5-2 $\mathrm{mm}$ ) was realized also by diode laser in the same regimen till visible superficial tissue coagulation. Coagulated flap tissues were refreshed slightly by hand currets ("Hu-Friedy"), removing the coagulated granulation tissue parts. After flap preparation, diode laser application was performed again pointwise (1-3 sec exposure per area) to provide hemostasis in area of curettage. In control group this stage was performed only due to hand currets (Hu-Friedy). After this, tissues and root surfaces were rinsed with $0.9 \% \mathrm{NaCl}$ for 1 min per each sextant, softly dried. The root surfaces were etched with "Pref Gel" (Straumann) for 2 min, rinsed with $0.9 \% \mathrm{NaCl}$ carefully for $2 \mathrm{~min}$, softly dried. The periodontal pockets were filled with "Emdogain" (Straumann) till tooth and bone surfaces were dried and cleaned from blood. The flap was adopted for wound closure, coronally repositioned. The wound was sutured with single modified internal mattress suture [2] using monofilament thread till complete wound closure. The sutured wound surface was covered with cellulose dressing Reso-Pac (Hager\&Werken).

In post-operative period, during 5 days the anti-iflammatory and analgetic therapy (Nimesulide $100 \mathrm{mg} \mathrm{X} 2$ times per day for 3 days, Cetirizin $0.01 \mathrm{mg}$ per day for 5 days) was prescribed. For oral hygienic irrigations "Angilex-Zdorovje" (Hexetidinum) was prescribed for a period of 14 days with rinsing for 3 times per day. The additional supra-gingival scaling was provided 2 times during healing period: on $7^{\text {th }}$ and $14^{\text {th }}$ day postoperatively. The control visits were provided after: 3,7,14 days. The sutures were removed after 14 days. The regular observations were provided after 1,3,6,9,12 months and included: an assessment of periodontal indexes (PI, BOP, PMA, PD, CAL), tooth morbidity. The first probing after flap operation was provided no earlier than 6 month post-operatively, X-ray examination was performed after 12 months. Complete hygienic recommendations were given to all patients and were controlled during each control visit every 4 month.

\section{Results}

The obtained clinical results showed effectiveness of provided treatment in both groups. But according estimation and comparison of the main periodontal indexed values (Figure 1) during hygienic and repeated pre-surgical phases, it is possible to conclude that reduction of inflammatory reaction in soft periodontal tissues is a dynamic process that actively continues during not less than 21 days according our preliminary results. Additional usage of diode laser irradiation may be beneficial and can reduce maturation time of tissues due to its bactericidal 
and simulative effects. The repeated presurcial phase provides additional staged reduction of PI, BOP, and PMA on $14^{\text {th }}-21^{\text {st }}$ day after initial therapy. Exactly initial progressive reduction of PI, BOP, PMA indexes can guarantee sufficient pre-surgical hygienic condition of periodontal tissues, less edema in them - which are crucial for chair time during surgical procedure, regenerative process and patients comfort in postoperative period.

According to the follow - up results after 1,3,6,9,12 month in both groups, slight progressive increase of PI, BOP, PMA indexes value continued from period of $1^{\text {st }}-6^{\text {th }}$ months post-operatively in the basic group and $1^{\text {st }}-9^{\text {th }}$ months - in control group. The maximal reduction of the same index values in control group were detected on $9^{\text {th }}$ month post-operatively with consequential slight increase from $9^{\text {th }}-12^{\text {th }}$ months. In contrast, the maximal reductions of the same indexes values in control group were detected on $12^{\text {th }}$ month. This data can give evidence about shortening of maturation time of periodontal tissues in basic group ( $9^{\text {th }}$ month $)$ in comparison with control group ( $12^{\text {th }}$ month), consequently accelerating regenerative processes. The increase of main indexing values in basic group was not significant, that can be connected with additional deep prolonged bactericidal and simulative effects of diode laser irradiation during surgical procedure.

Comparing the mean values of main indexes (Table 4) 1 year post-operatively, it is possible to conclude that index values were lower in basic group; especially the significant difference was detected in values of PI and BOP, which are crucial for long-term clinical results and GP remission. This data can lead to hypothesis about long-term bactericidal effect in periodontal tissues due to laser irradiation.

The initial periodontal pocket depth reduction on 1-2 mm maximally, was detected after pre-surgical phase (on $14^{\text {th }}$, $21^{\text {st }}$ day) and continued till $6^{\text {th }}$ month post-operatively, due to influence of provided procedures on residual marginal periodontal tissues edema in both the groups, also the first probing was realized after 6 months postoperatively (Table 5). Such positive results can be explained by influence of diode laser irradiation on marginal periodontal tissues during curettage. The reduction of pocket depth in basic group started from $6^{\text {th }}$ month post-operatively and continued till $12^{\text {th }}$ month. In comparison of control group and indexes, the reduction started later - on $9^{\text {th }}$ month post-operatively. After 12 months the indexes values were the same in both the groups.

The preliminary results may indicate the positive effect of tissues preservation due to additional diode laser usage during surgical phase and positive clinical effect from combination of diode laser irradiation and EMD - "Amdogain" (Strauman) on reduction of maturation time in periodontal tissues and earlier continuous regenerative process after surgical procedures. That can be crucial for further restorative procedures. Additional diode laser usage during different treatment stages: pre-surgical and surgical phase may reduce healing and maturation time of periodontal tissues, promoting the regeneration, supplying the long-term continuation of obtained clinical result.

Comparing the chair time during providing flap operation in both groups, it is possible to conclude that additional usage of diode laser may reduce it from $60 \mathrm{~min}$ to $40 \mathrm{~min}$. The standard curettage provided by usage of hand currets may prolong the surgical procedure because of less working comfort due to bleeding and less visual ability, especially during residual granulations elimination in deep pockets, appearance of more risks for flap trauma by sharp instrument. As consequence, these details may influence on prolongation of regeneration period postoperatively (Figures 2 and 3, Table 5).

The additional usage of diode laser during surgical phase may enhance the clinical results, reducing chair time and promoting regeneration in earlier terms that was reached in basic group (Tables 5 and 6). This can be explained by main effects of used diode laser: bactericidal, simulative. It can be assumed that combined usage of hand instruments and diode laser for curettage may be beneficial due to tissue preservation, less bleeding, simultaneous deep bactericidal effect, guaranteed elimination of residual granulations from flap (even in patients with thin

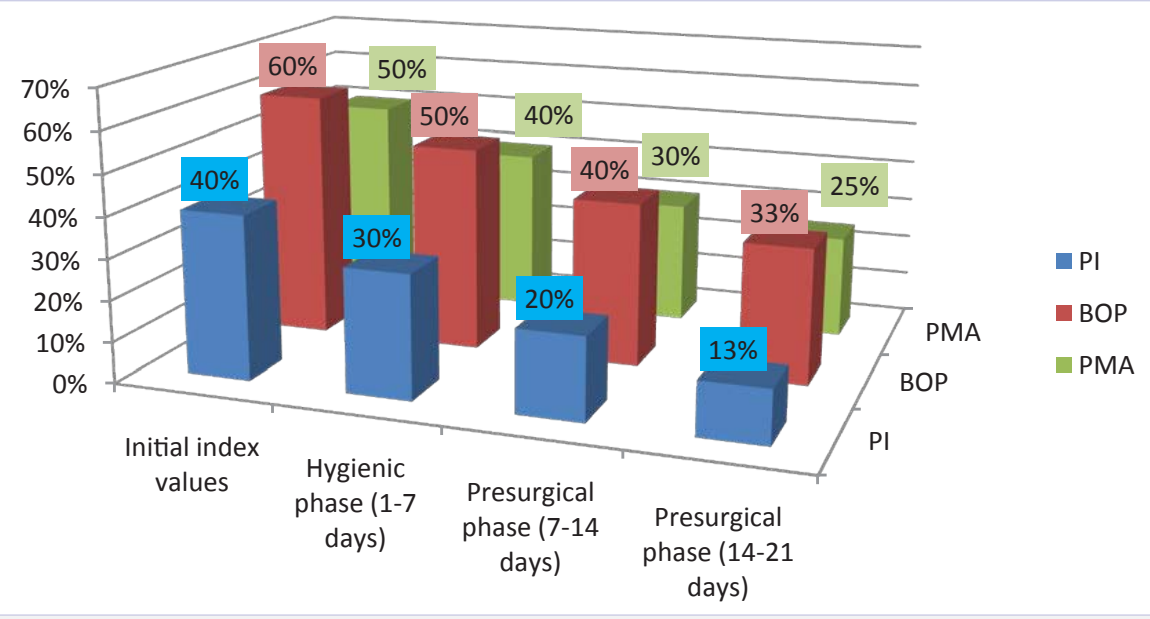

Figure 1: Dynamic indexes values during hygienic and presurgical stages in basic and control groups of patients. 
Table 4: The comparison of mean values of main indexes in basic and control groups after 1 year post-operatively.

\begin{tabular}{|c|c|c|}
\hline \multirow{2}{*}{ Index type } & \multicolumn{2}{|c|}{ Group } \\
\cline { 2 - 3 } & Basic & $26.6 \%$ \\
\hline PI & $18.2 \%$ & $33.8 \%$ \\
\hline BOP & $29.8 \%$ & $29 \%$ \\
\hline PMA & $28 \%$ & \\
\hline
\end{tabular}

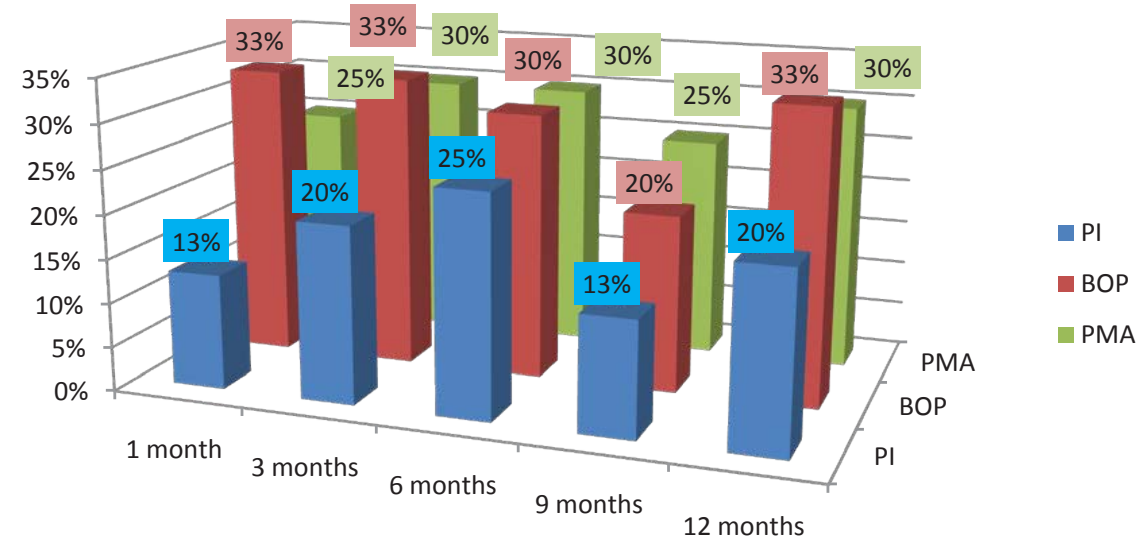

Figure 2: The follow-up indexes values in basic group.

Table 5: The comparison of dynamic periodontal pocket reduction after treatment phases.

\begin{tabular}{|c|c|c|}
\hline \multirow[t]{2}{*}{ Terms (months) } & \multicolumn{2}{|c|}{$\begin{array}{l}\text { Periodontal pocket depth }(\mathrm{mm}) \\
\text { in presented groups of patients }\end{array}$} \\
\hline & Basic group & Control group \\
\hline Hygienic phase (1-7 days) & \multicolumn{2}{|c|}{$5-7 \mathrm{~mm}$} \\
\hline Presurgical phase (14-21 days) & \multirow{4}{*}{\multicolumn{2}{|c|}{$4-6 \mathrm{~mm}$}} \\
\hline Surgical phase & & \\
\hline 1 month & & \\
\hline 3 months & & \\
\hline 6 months & $3-5$ & $4-6$ \\
\hline 9 months & $2-4$ & $3-5$ \\
\hline 12 months & \multicolumn{2}{|c|}{$2-4$} \\
\hline
\end{tabular}

Table 6: The comparison of chair time during provided procedures in main groups of patients.

\begin{tabular}{|c|c|c|c|}
\hline Group & Treatment phase & $\begin{array}{l}\text { Curretage } \\
\text { (methodic) }\end{array}$ & Chair time (min) \\
\hline Basic & \multirow[b]{2}{*}{ Surgical phase } & Hand currets & $60 \mathrm{~min} \pm 20 \mathrm{~min}$ \\
\hline Control & & $\begin{array}{l}\text { Hand currets+ } \\
\text { laser curretage }\end{array}$ & $40 \mathrm{~min} \pm 20 \mathrm{~min}$ \\
\hline
\end{tabular}

gingival phenotype) and deep pockets, hard to reach places. Simultaneous flap laser deepithelization promotes simplification of the surgical stage, absence of additional tissue cuts, procedure time reduction, working comfort for operator. Also usage of diode laser during surgical phase supplies enough hemostasis in wound, which is crucial for work with EMD according instruction. It is very comfortable and easy to etch the root surfaces, clean them and fill the prepared bone pockets with EMD "Amdogain" (Straumann) before blood will reach the wound. The combined usage of diode laser and EMD may have benefits during surgical procedure and healing process.

\section{Conclusions}

The significant inflammatory reduction in periodontal tissues should be achieved on pre-surgical stage. The initial periodontal tissue condition may influence the healing in postsurgical period. Deep staged pocket decontamination and de-granulation should be provided on pre-surgical stage. The presented preliminary clinical results showed that additional diode laser usage during pre-surgical and surgical phases 


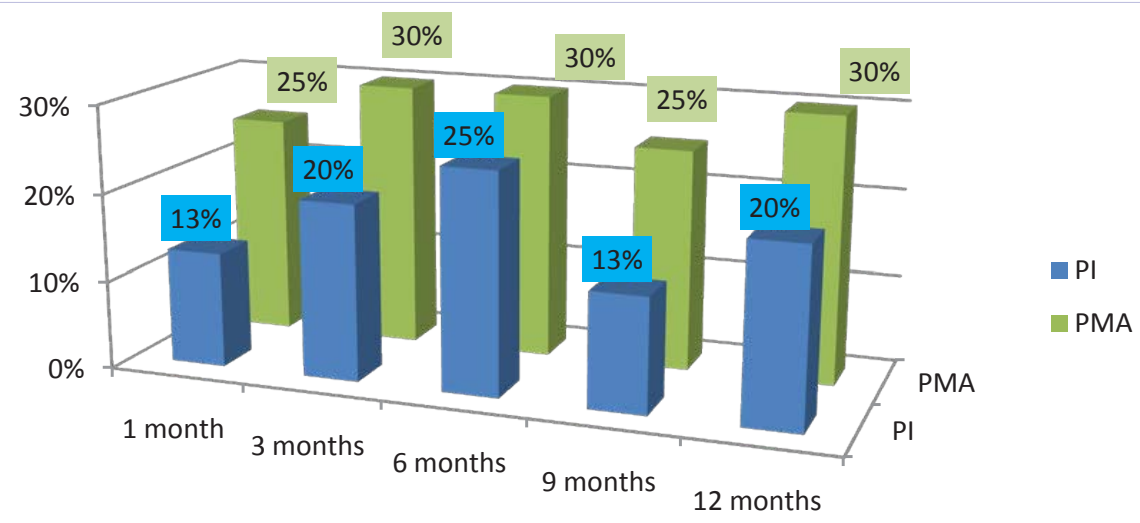

Figure 3: The follow-up indexes values in control group.

may be beneficial due to bactericidal, simultaneous effects, preservation of marginal periodontal tissues, promotion of progressive regeneration process, long-term remission of GP. Also the reduction of main periodontal indexes values is staged process that can be accelerated by diode laser irradiation usage. The sufficient periodontal tissues preparation on pre-surgical stage, may guarantee long-term clinical success after surgery. It is possible to proceed to surgical stage after 21 days after applied hygienic and pre-surgical stages in combination with diode laser irriadiation under regular reevaluation of main periodontal indexes in patients with moderate GP. Combined usage of diode laser irradiation and "Amdogain" may provide periodontal regeneration without usage of additional materials. The surgical phase may be simplified regarding additional working comfort, tissue preservation, deep simultaneous bactericidal, simulative effects, hemostasis and reduced chair-time. Such approach can become economically reasonable for patients, less traumatic and comfortable in postsurgical period, which can be also for patients in country like Ukraine.

\section{Acknowledgement}

I would like to thank to Prof. Biloklytska G., Prof. Shapira L., Prof. Goldstein M., Prof. Cortellini P., Prof. Tonetti M., Prof. Van Dyke T.,Prof. Sculean A., Prof. Demirel K. Drs: Reners M., Lolke van Dijk J., Bozic D., Shiyovich A., Tkachuk N., Panchenko L., Fesenko E. for their contribution and inspiration in development of this manuscript.

\section{References}

1. Andreana S, Christersson LA, Fransson CL. The effect of subgingival scaling on the patient and site distribution of periodontal bacteria. J Dent Res. 1991; 70: 119.

2. Andreana S. The usage of diode lasers in periodontal therapy: literature review and suggested technique. Dent Today. 2005, 24(11): $130,132-5$.

3. Coleton S. Lasers in surgical periodontics and oral medicine. Dent Clin North Am. 2004; 48(4): 937-62.

4. Cortellini P, Tonetti MS. Clinical performance of a regenerative strategy for intrabony defects: scientific evidence and clinical experience. J Periodontol. 2005; 76(3): 341-50.

5. Cortellini P, Tonetti MS. A Minimally Invasive Surgical Technoque
(MIST) with Enamel Matrix Derivate in the Regenerative Treatment of Intrabony Defects: A Novel Approach to Limit Morbidity. J Clin Periodontol. 2007; 34(1): 87-93.

6. Esposito M, Grusovin MG, Papanikolaou N, Coulthard P, Worthington HV. Enamel matrix derivative (Emdogain) for periodontal tissue regeneration in intrabony defects. A Cochrane systematic review. Eur J Oral Implantol. 2009; 2(4): 247-66.

7. Hammarstrom L. Enamel matrix, cementum development and regeneration. J Clin Periodontol. 1997; 24: 658-668.

8. Harrel SK, Rees TD. Granulation tissue removal in routine and minimally invasive surgical procedures. Compend Contin Educ Denti. 1995; 16(9): 960-964.

9. Iorio-Siciliano V, Andreuccetti G, Blasi A, Matarasso M, Sculean A, Salvi GE. Clinical Outcomes Following Regenerative Therapy of Non-Contained Intrabony Defects Using Deproteinized Bovine Bone Mineral Combined With Either Enamel Matrix Derivative or Collagen Membrane. J Periodontol. 2014; 85(10): 1342-50. doi: 10.1902/ jop.2014.130420.

10. Kreisler M, Christoffers AB, Willershausen B, d'Hoedt B. Effect of low-level GaAlAs laser irradiation on the proliferation rate of human periodontal ligament fibroblasts: an in vitro study. J Clin Periodontol. 2003; 30(4): 353-58.

11. Leung G, Jin L. A combined approach of enamel matrix derivative gel and autogenous bone grafts in treatment of intrabony periodontal defects. A case report. Prim Dent Care. 2003; 10(2): 41-3.

12. Mavrogiannis M, Thomason JM, Seymor RA. Lasers in periodontology. Dent Update. 2004; 31(9): 535-47.

13. Miron RJ, Caluseru OM, Guillemette V, Zhang Y, Gemperli AC, Chadad, et al. Influence of Enamel Matrix Derivative on Cells at Different Maturation Stages of Differentiation. PLoS ONE. 2013; 8(8): e71008. doi:10.1371/journal.pone.0071008.

14. Moritz A, Gutknecht N, Doertbudak O, Goharkhay K, Schoop U, Schauer $\mathrm{P}$, et al. Bacterial reduction in periodontal pockets through irradiation with diode laser: a pilot study. J Clin Laser Med Surg. 1997; 15(1) :3337.

15. Moritz A, Schoop U, Goharkhay K, Schauer P, Doertbudak O, Wernisch J, et al. Treatment of periodontal pockets with diode laser. Lasers Surg Med. 1998; 22(5): 302-311.

16. Sakurai Y, Yamaguchi M, Abiko Y. Inhibitory effect of low-level laser irradiation on LPS-stimulated prostaglandin E2 production and 
cyclooxygenase- 2 in human gingival fibroblasts. Eur J Oral Sci. 2000 108(1): 29-34.

17. Sculean A, Hägi TT, Laugisch O, Ivanovic A. Periodontal regenerative therapy. Quintessence Int. 2014; 45(3): 185-92. doi: 10.3290/j. qi.a31203.

18. Sculean A, Donos N, Brecx M, Reich E, Karrig T. Treatment of intrabony defects with enamel matrix proteins and guided tissue regeneration: an experimental study in monkeys. J Clin Periodontol. 2000; 27(7): 466-72.
19. Miron RJ, Bosshardt DD, Laugisch O, Dard M, Gemperli AC, Buser D, et al. Enamel Matrix Proteins And Periodontal Wound Healing And Regeneration. J Periodontol. 2013; 84(11): 1646-54. doi: 10.1902/ jop.2013.120574.

20. Szatmári P, Gera I. Treatment of localized intrabony periodontal defects with enamel matrix derivative (Emdogain). Case series. Fogorv Sz. 2014; 107(1):15-28. 